\title{
PRZEMIANY MODELU HANDLU FORMATAMI TELEWIZYJNYMI W WYMIARZE KULTUROWYM I EKONOMICZNYM
}

\section{Abstract \\ CHANGES IN THE MODEL OF TRADE IN TELEVISION FORMATS IN THE CULTURAL AND ECONOMIC DIMENSION}

In response to the changing television market, media organizations create strategic solutions to affect the format trading system that has been stable so far. For two decades, a model of format trade has allowed finding balance in the conceptual frame set by the opposition: adaptation versus creation, broadcasters versus production companies, global versus local conditions, business and cultural values.

The purpose of the article is to preliminarily describe how these strategic and operational activities undertaken by global organisations disturb this balance. Taking control of format production by subsidiaries of foreign capital, new distribution channels may result in a smaller share of broadcasters in creation, universalization of formats lacking local accents, weakening the brand of entities identified on local markets.

Key words: global format, television company, television production, brand, globalization, glocalization

\section{Wprowadzenie}

Nadmiar telewizyjnego kontentu, rozdrobnione audytorium, nowe praktyki odbiorcze widzów - to główne czynniki zmian, które obserwujemy na telewizyjnym rynku. Celem tego artykułu jest opisanie, jak te przeobrażenia wpływają na handel globalnymi formatami, który od dwóch dekad dominuje w telewizyjnej rzeczywistości. 
Przez lata nadawcy inwestujący w zakup licencji osiągali bezpieczne zyski, mogli oszacować nakłady i zwroty z inwestycji. Handel formatami bywał nazywany stabilnym systemem [Chalaby 2016, s. 38], w którym role pomysłodawcy, dystrybutora, producenta i nadawcy są jasno zdefiniowane, a prawne i ekonomiczne regulacje - wyraźnie określone. Na straży tego porządku stoi FRAPA (Format Recognition and Protection Association), organizacja zrzeszająca autorów, producentów, nadawców (do 2019 roku stowarzyszenie zarejestrowało około 500 członków).

Handel formatami ma jednak nie tylko wymiar ekonomiczny, ale także ściśle z nim związany wymiar kulturowy. Licencja obejmuje jedynie przepis na program telewizyjny, zatem zdefiniowane przez nią globalne ramy musi wypełnić lokalna treść. Format odniesie sukces ekonomiczny, jeśli zostanie dostosowany do wymagań krajowej widowni, wyda się jej swojski, bliski, rodzimy.

$\mathrm{W}$ ostatnim okresie organizacje medialne, zmuszone przez wymienione powyżej czynniki zmian, wdrażają strategie, które silnie wpływają na stabilny dotąd model handlu formatami. Modyfikują system produkcji i dystrybucji, a w konsekwencji naruszają globalno-lokalny dualizm powstających programów telewizyjnych. Wzrasta i dominuje rola twórcy formatu oraz właściciela licencji, maleje rola lokalnych producentów i nadawców.

Celem badawczym jest zatem opisanie, jakie skutki ekonomiczne, społeczne i kulturowe niosą opisane w dalszej części artykułu działania graczy telewizyjnych i w jakim stopniu wpływają na utrwalony system zależności między kreatorami, dystrybutorami, producentami i nadawcami formatu. Pytania badawcze będą dotyczyć przede wszystkim strategicznych lub operacyjnych wysiłków organizacji medialnych, które stanowią odpowiedź na nowe praktyki odbiorców, nadmiar kontentu i rozdrobnienie audytorium. Artykuł stanowi krytyczny przegląd głównie zagranicznego stanu badań w tym zakresie.

Zanim jednak podejmiemy próbę odpowiedzi na powyższe pytania, spójrzmy na zarys dotychczas funkcjonujących procesów oraz na opis głównych podmiotów i przedmiotów w zarządzaniu formatami.

\section{Format telewizyjny - definicje}

W literaturze przedmiotu możemy znaleźć liczne definicje terminu „format telewizyjny". Ich różnorodność wynika ze sposobu ujmowania przez autorów samego definiens omawianego pojęcia; na przykład część badaczy skupia uwagę tylko na budowie i strukturze formatów. W tym artykule skoncentrujemy się jednak na przykładach, które biorą pod uwagę przede wszystkim wymiar ekonomiczny. W takim ujęciu:

- format telewizyjny to program lub pomysł na program, $\mathrm{z}$ wyodrębnionymi elementami, które mogą być przedmiotem licencji sprzedawanej firmom produkcyjnym lub nadawcom do lokalnej adaptacji [Schmitt 2005]; 
- sprzedaż formatu dotyczy specyficznego produktu zawierającego przepis na lokalną adaptację programu telewizyjnego, który odniósł wcześniej sukces na innym rynku [Bodycombe 2005].

Według ostatniej definicji format jest przede wszystkim „przepisem na program", przygotowanym pakietem zaleceń i instrukcji, obejmującym też opis know-how. Ten zestaw jest wcześniej przetestowany w postaci zrealizowanej oraz wyemitowanej produkcji. Jeśli format cieszy się sukcesem na swoim pierwotnym rynku, wzrasta prawdopodobieństwo, że zdobędzie popularność w kraju importera.

Format możemy zatem zdefiniować jako telewizyjny program, który jest przedmiotem handlu. Nadawcy telewizyjni muszą wykupić licencję od twórców i na zasadzie franczyzy wyprodukować format lub tylko finansować produkcję. Po sfinalizowanej transakcji nadawcy otrzymują tak zwaną biblię formatu, zawierającą wiele szczegółowych instrukcji odnoszących się do: scenariusza, realizacji obrazu, realizacji dźwięku, narracji, występujących w programie osób, postprodukcji, ale także kwestii finansowych i prawnych. Oczywiście program wyprodukowany na podstawie sprzedanej licencji musi respektować narodową, kulturalną, ideologiczną i obyczajową specyfikę danej widowni. To przystosowanie odbywa się na wielu płaszczyznach i wymaga od lokalnych producentów wrażliwości oraz znajomości gustu rodzimego widza. Reprodukcja oryginału musi respektować wartości kulturowe lokalnego audytorium. Dotyka zatem innego, istotnego wymiaru formatu telewizyjnego, który odnosi się do kultury. Bez umiejętnego tłumaczenia uwzględniającego te wartości lokalna wersja nie osiągnie sukcesu ekonomicznego.

Jak ujmuje to jeden z producentów telewizyjnych:

Ludzie lubią oglądać samych siebie na ekranie, swoje życie i w tych formatach często mamy do czynienia ze zwykłymi ludźmi odnoszącymi sukcesy, zarabiającymi pieniądze, stającymi się gwiazdami popu, tancerzami, znajdującymi pracę w biznesie - (niemieccy) widzowie nie chcą oglądać Amerykanów znajdujących pracę, tylko widzieć Niemców [Moran 2009, s. 81].

Właściciel licencji może zezwolić kupującemu na dostosowanie formatu do oczekiwań i potrzeb danego rynku telewizyjnego. Jednak odejście od pierwotnego wzorca zawsze stanowi przedmiot negocjacji między licencjodawcą a licencjobiorcą. Chodzi w istocie o uzyskanie równowagi pomiędzy globalną standaryzacją i lokalną różnorodnością.

Formaty można opisywać w czterech wymiarach [Chalaby 2016]:

- Po pierwsze, format jest to remake wyprodukowany na bazie licencji. Pozwala kupującemu stworzyć lokalną wersję oryginalnego programu, dostosowując go do wymagań rodzimej widowni.

- Po drugie, format jest przepisem, który zawiera zarówno stałe, niezmienne zasady, jak i wskazówki, które mogą być modyfikowane podczas adaptacji. Format nie jest produktem, tylko wehikułem, którym podróżuje pewna telewizyjna koncepcja programu, przekraczając granice krajów i kultur. 
- Po trzecie, format uprawdopodabnia komercyjny sukces. Towarzyszą mu szczegółowe dane dotyczące oglądalności lokalnych wersji, analizy audytorium z podziałem na standardowe grupy reprezentatywne (według wieku, płci, zamieszkania itd.). Jeśli format nie gwarantuje sukcesu, pozwala przynajmniej na zarządzanie ryzykiem typowym dla produkcji i emisji nowego programu.

- Po czwarte, format definiuje metody produkcji. Kupujący licencję otrzymuje tzw. biblię formatu, która zawiera instrukcje potrzebne do produkcji programu. Szczegółowe informacje dotyczą np. budżetu, formatu scenariuszy, ustawienia scenografii, grafiki, zasad castingu, profilu gospodarza, selekcji uczestników. Instrukcje są aktualizowane po każdej lokalnej produkcji formatu.

\section{Podstawowe procesy i podmioty obecne w handlu formatami}

Międzynarodowy handel formatami obejmuje powtarzające się procesy:

- rozwoju,

- produkcji,

- dystrybucji,

- adaptacji,

- emisji formatu.

Wymienione procesy odbywają się niejako w dwóch cyklach:

- pierwotnym, rozpoczynającym się od pomysłu na format, poprzez pierwszą jego produkcję, emisję i późnej dystrybucję;

- wtórnym, inicjowanym przez kupno licencji i kontynuowanym przez redystrybucję, adaptację, reprodukcję i emisję.

Oczywiście wtórny cykl jest powielany wobec każdej kolejnej adaptacji. Sam proces kupowania zagranicznych formatów wymaga podejmowania przez szefów spółek medialnych decyzji, które mają wymiar ekonomiczny i kulturowy. Trzeba oszacować: opłacalność inwestycji, wysokość budżetu produkcji, docelową grupę odbiorców, zastanowić się nad miejscem w ramówce. Przewidzieć, czy zakupiony format zostanie dobrze przyjęty przez widzów, a zatem czy wpasuje się w społeczno-kulturowy kontekst.

Przykładowo dubbingowane lub lokalne wersje typowych amerykańskich oper mydlanych nie cieszą się popularnością w krajach Ameryki Łacińskiej, ponieważ tamtejsza widownia nie lubi seriali z dużą liczbą odcinków, wieloma wątkami, które się komplikują, nigdy nie kończą, a cechują się stałym przetasowaniem postaci i aktorów. Szefowie stacji są zainteresowani serialami, które mają wyraźny początek i koniec, mogą być w prosty sposób kontynuowane lub zakończone, zależnie od wyników oglądalności. Dlatego stacja TELEFE wybrała do produkcji serial The Nan$n y$ spośród wielu sitcomów oferowanych przez Sony. Nadawcy chcieli pokazywać 
sitcom codziennie, potrzebowali zatem takiego z wystarczającą liczbą odcinków. Decyzja była podyktowana ekonomicznym rachunkiem i wiedzą o przyzwyczajeniach argentyńskiego widza [Waisbord 2016].

Kiedy format już zostanie zakupiony, rozpoczyna się proces adaptacji, który ma dwa wymiary: pierwszy polega na eliminowaniu niezrozumiałych lub obcych kulturowo cech programu i dodawaniu elementów istotnych dla lokalnego widza; drugi zakłada stałe monitorowanie procesu kreowania i reagowanie na bieżącą sytuację polityczną, ekonomiczną oraz społeczną.

O wiele trudniejsze i bardziej złożone wydaje się antycypowanie przez gatekeeperów (szefów spółek medialnych, programatorów i producentów) gustów oraz nastrojów rodzimej widowni; wiedza o tym, które elementy formatu okażą się „lost in translation" - które treści mogą obrazić widownię, które okażą się nazbyt ekscentryczne, obce lub zbyt uniwersalne. A także: które historie pozwolą osadzić akcję programu w rzeczywistości społecznej danego kraju.

Do szeroko komentowanych w historii telewizji błędów gatekeeperów należała decyzja wyprodukowania Al-Ra'is (arabskiej wersji Big Brothera). Program, wyemitowany w 2004 roku w Bahrajnie, został zdjęty z anteny w wyniku zaostrzających się protestów. Zdaniem konserwatystów program naruszał wartości islamu poprzez zamykanie w jednej przestrzeni niezamężnych młodych kobiet i mężczyzn. Producenci saudyjskiej telewizji MBC próbowali co prawda ustrzec się przed głosami krytyki: wybrali do emisji programu liberalny Bahrajn, zaprosili do programu wyłącznie rozwiedzione kobiety. Po tygodniu emisji stacja musiała jednak zatrzymać emisję.

Badacze identyfikują istotny czynnik, który wpływa na te umiejętności przewidywania gustów audytorium [Waisbord 2016]. Jest nim rodzaj „dziennikarskiej wrażliwości”, która pozwala nie tylko na trafną analizę potrzeb widzów, lecz także na swoiste współodczuwanie tych pragnień, wsłuchiwanie się w puls teraźniejszości i przyszłości. W tym kontekście kultura narodowa oznacza dla gatekeeperów odniesienie nie tyle do mitów narodowych, symboli patriotycznych, przełomowych wydarzeń historycznych, ile raczej do ostatnich, dzielonych przez mieszkańców doświadczeń. Mniej dotyczy przeszłości, bardziej teraźniejszości i przyszłości. Audytorium postrzega się zatem jako społeczność, która ostatnio wspólnie czegoś doświadczyła, przeżyła ważne chwile.

\section{Czynniki zmian}

Dzisiaj na rynku telewizyjnym możemy obserwować wyraźną nadprodukcję formatów. W 2015 roku w samym USA wyemitowano 750 programów reality show, z których połowa miała wówczas swoją premierę [Torre 2017, s. 120]. Nadmiar kontentu telewizyjnego doprowadził do spadku oglądalności reality tv, który można tłumaczyć znużeniem widza powtarzalnością stosowanych rozwiązań. Tej tendencji nie 
oparły się nawet najsłynniejsze superprodukcje. Zawieszono i wznowiono emisję American Idol, ratingi Survivora, The Voice, Celebrity Apprentice, Dancing with the Stars wskazują na stale zmniejszające się zainteresowanie widowni [Torre 2017].

Wydaje się, że minął już czas rekordów oglądalności bitych przez globalne formaty. Spoglądając na badania Nielsen Audience Measurement, odnoszące się do polskiego rynku w 2019 roku, od razu można zauważyć wyraźną tendencję spadkową w odniesieniu do lat ubiegłych. $Z$ roku na rok liczba widzów oglądających tradycyjną telewizję zmniejsza się.

1. MasterChef (TVN, 7. seria, emisja 09.2019), średnia po trzech odcinkach 1,9 mln w grupie $4+$, liczba widzów spadła o 230 tys. w odniesieniu do poprzedniej edycji ${ }^{1}$.

2. Top Model (TVN, 8. edycja, emisja 09.2019) średnia po trzech odcinkach $1,28 \mathrm{mln}$ w grupie $4+$, liczba widzów spadła o 320 tys. w odniesieniu do poprzedniej edycji ${ }^{2}$.

3. Taniec z gwiazdami (Polsat, 9. edycja, emisja 03.2019) średnia po trzech odcinkach $-2,68 \mathrm{mln}$ w grupie $4+$, liczba widzów spadła o 420 tys. w odniesieniu do poprzedniej edycji ${ }^{3}$.

Oczywiście badacze oglądalności mogą uzasadnić te wyniki innymi czynnikami: pogodą, otoczeniem konkurencyjnym lub okolicznościami związanymi z samą zawartością programu. Jednak spadki oglądalności dotyczą ramówek większości stacji telewizyjnych na całym świecie. Mówi się zatem o nowych praktykach odbiorczych, które nie pozwalają widzom na śledzenie programu w tradycyjnej telewizji. W Polsce ta tendencja nie jest jeszcze tak gwałtowna, jak na innych rynkach. W większości krajów nordyckich (Danii, Norwegii, Finlandii, Szwecji) od roku 2010 zanotowano wyraźny spadek oglądalności telewizji tradycyjnej we wszystkich grupach wiekowych. Widzowie przerzucili się na oglądanie programów na platformach online, na VOD, SVOD, wybrali Netflix oraz YouTube (młodsza generacja).

Podobną tendencję można obserwować na amerykańskim rynku telewizyjnym - widzowie odchodzą od śledzenia tradycyjnej telewizji naziemnej lub kablowej do platform online, oglądanych na tabletach, laptopach i innych mobilnych urządzeniach.

Nadawcy w większości krajów muszą zmierzyć się zatem z pojawieniem się nowej widowni, nielojalnej wobec tradycyjnej telewizji i zainteresowanej nowymi technologiami, pozwalającymi między innymi na interaktywność.

1 Zob. https://www.wirtualnemedia.pl/artykul/1-9-mln-widzow-masterchefa-8-tvnzdecydowanym-liderem-w-16-49 (dostęp: 8.02.2020).

2 Zob.https://www.wirtualnemedia.pl/artykul/top-model-tvn-8-sezon-ogladalnosc-programstracil-320-tys-widzow (dostęp: 8.02.2020).

3 Zob. https://www.wirtualnemedia.pl/artykul/ogladalnosc-tanca-z-gwiazdami-programpolsatu-stracil-widzow (dostęp: 8.02.2020). 


\section{Nadawcy, producenci, dystrybutorzy formatów w dobie schyłku tradycyjnej telewizji}

Śmierć tradycyjnej telewizji jest podobno ogłaszana od połowy lat dziewięćdziesiątych [Van den Bulck, Enli 2014]. Pojawia się pytanie: na jakim etapie znajduje się przemysł formatów telewizyjnych - fragmentacji, selekcji, dojrzałości czy schyłku?

W fazie fragmentacji pojawiają się nowe produkty, na etapie selekcji ostra konkurencja sprzyja ich rozwojowi, w fazie dojrzałości następuje stabilizacja, a w czwartej - schyłkowej - rynek jest całkowicie zaspokojony.

Z pozoru odpowiedź wydaje się prosta: przemysł formatów jest $\mathrm{w}$ fazie schyłkowej. Obrazu dopełnia stały spadek oglądalności tradycyjnej telewizji, skutkujący zmniejszającymi się dochodami z reklam. Jednak w istocie badania wskazują na to, że audytorium telewizyjne poszerza się, a rynek pogłębia [Torre 2017]. Kryzys dotyczy zatem jedynie „starej” telewizji. Gracze medialni muszą więc odpowiedzieć na pytanie o skuteczne strategie w docieraniu do coraz trudniejszego odbiorcy. Nowe koncepcje muszą dotyczyć dróg dystrybucji formatów, zarządzania markami i wreszcie nowej jakości produkowanego kontentu. Trzeba zauważyć, że za każdą z tych strategii kryje się wyraźna ekspansja rozwiązań narzucanych przez globalne spółki medialne lokalnym organizacjom.

\section{Nowy model produkcji formatów}

W 2014 roku doszło do połączenia dwóch ważnych spółek telewizyjnych: brytyjskiego Shine'a i holenderskiego Endemola. Nowa organizacja Endemol Shine Group połączyła trzy role: twórcy formatu, dystrybutora i producenta. Wcześniej $\mathrm{w}$ historii handlu formatami podmioty te występowały $\mathrm{w}$ różnych zależnościach [Chalaby 2016]:

1. twórca, dystrybutor, producent reprezentują jedną spółkę;

2. twórca reprezentuje jedną spółkę, dystrybutor i producent drugą;

3. twórca i dystrybutor należy do jednej spółki, producent reprezentuje drugą;

4. twórca i producent tworzą jedną spółkę, dystrybutor drugą;

5. twórca należy do jednej spółki, dystrybutor do drugiej i producent do trzeciej.

Kupujący licencję nadawcy mogli sami wyprodukować format (jeśli dysponowali produkcją in house), mogli zlecić realizację zaufanej spółce zewnętrznej, wreszcie zdać się na podmiot sprzedający licencję, jeśli dysponował takim zapleczem.

Jednak w ostatnich latach wśród właścicieli formatów można zaobserwować wyraźną tendencję do ograniczania nadawcom tych możliwości, na przykład na polskim rynku telewizyjnym przy pierwszych edycjach programu MasterChef brytyjski Shine (twórca) poprzestał na sprzedaży licencji i ogólnych wskazówkach dla 
producentów formatu. Jednak nowa spółka Endemol-Shine zmieniła zasady współpracy. Dzisiaj produkuje show dla TVN, mimo że nadawca dysponuje dużymi możliwościami produkcji in house. Wydaje się, że opisana zmiana wynika $\mathrm{z}$ dążenia twórcy i dystrybutora do sprawowania całkowitej kontroli nad formatem. W tym modelu nadawca nie uczestniczy w procesie kreacji, ograniczając się do zatwierdzania poszczególnych odcinków.

Podobną tendencję można zauważyć w Finlandii [Nyland 2016, s. 12]. Szefowie fińskich stacji telewizyjnych podkreślają, że po zakupie licencji mieli dowolność $\mathrm{w}$ wyborze spółki, która wyprodukuje im produkt. Teraz nie jest to możliwe, prawa do produkcji są powiązane z jedną określoną lokalną spółką, zależną od twórcy i dystrybutora formatu. Szefowie stacji telewizyjnych widzą tę zmianę w kategoriach istotnego ograniczenia ich wolności wyboru.

W ostatnich latach w Finlandii dokonała się wyraźna zmiana struktury własności mediów i obecnie większość spółek produkcyjnych pozostaje pod kontrolą zagranicznego kapitału. Równowaga między lokalną i globalną własnością w fińskich spółkach została silnie zachwiana [Nyland 2016, s. 12].

Badacze zwracają uwagę, że łańcuch wartości w zarządzaniu formatami znajduje się obecnie pod kontrolą globalnego kapitału [Nyland 2016; Chalaby 2016]. Oznacza to, że w wymiarze ekonomicznym została zachwiana opisana w poprzednich rozdziałach harmonia pomiędzy czynnikami globalnymi i lokalnymi. Dla nadawców ta sytuacja oznacza, że mają mniejszą kontrolę nad emitowanym na swojej antenie formatem. Nie uczestniczą w procesie kreacji i ich rola jako gatekeeperów wydaje się mocno rozmyta. Oczywiście, zawsze mogą zakwestionować wyprodukowany kontent, jednak realizacja niektórych programów reality $t v$, np. Big Brothera, bardzo utrudnia taką ingerencję; ze względu na to jest to tzw. format non-scripted, nie podlega tradycyjnemu scenariuszowi, a akcja rozwija się często spontanicznie. Ponadto spółki zależne mają w opisanej sytuacji większą kontrolę nad prawami autorskimi do emitowanego kontentu [Chalaby 2016, s. 38], co w świecie medialnym opisanym przez koncepcję long tail stanowi istotne ograniczenie dla nadawców.

\section{Nowe drogi dystrybucji formatów}

Utworzenie nowych możliwości dystrybucji formatów stało się dla wielu spólek warunkiem przetrwania na nasyconym produkcjami telewizyjnymi amerykańskim rynku. Opisane połączenie Shine i Endemola stanowi zaledwie jeden z wielu przykładów konsolidacji organizacji medialnych w ostatnich latach (ostatnio grupa Endemol-Shine została zakupiona i sprzedana przez Disneya, a obecnie jest własnością Banijay Group). 
Strategie przejmowania i łączenia spółek realizują sześć istotnych celów:

- przyniesienie nowej kreatywności i energii do spółki;

- zabezpieczenie wiedzy produkcyjnej o najlepszych praktykach;

- pozyskanie dodatkowych relacji z producentami i obecnymi na rynku talentami;

- pozyskanie dodatkowej biblioteki kontentu, nawet jeśli prawa do niego są ograniczone;

- rozszerzenie marki i reputacji spółki;

- otwarty dostęp do nowych rynków - lokalnych i międzynarodowych [Torre 2017].

W roku 2018 koncern Discovery Communications przejął 100\% akcji Scripps Networks, otwierając sobie drogę do portfolio zawierającego między innymi kanały tematyczne HGTV, Food, Travel, TVN Style, Turbo, oraz do bogatej biblioteki kontentu. Spółka stworzyła sobie zatem dodatkowe możliwości dystrybuowania swojej oferty. Discovery w wyniku przejęcia stało się także właścicielem grupy TVN, która reprezentuje wciąż dość tradycyjną strategię myślenia o zarządzaniu kontentem i o kanałach dystrybucji. Konferencje ramówkowe wskazują na to, że TVN planuje zysk, kompletując ograniczony wachlarz produktów, które przyciągną uwagę widowni. Na tę ofertę składają się zarówno adaptacje globalnych formatów, jak i rodzime produkcje. Tymczasem strategia Discovery opiera się raczej na koncepcji opisanej przez Chrisa Andersona jako long tail [Anderson 2006]. Koncepcja „długiego ogona” oznacza, że zyski dystrybutorów kontentu wynikają z agregowania dużej liczby produktów zarówno popularnych, jak i niszowych. Raz wyprodukowany produkt medialny musi zostać wielokrotnie sprzedany i znaleźć widzów na różnych platformach komunikacyjnych (Discovery działa na około 220 rynkach na całym świecie). Efekt long tail sprawia, że nadawcy produkują taniej i więcej. Na pewno każda złotówka przeznaczona na telewizyjną produkcję jest wielokrotnie oglądana. A jednak sam TVN, mimo że należy do grupy Discovery, nadal kupuje licencje na drogie formaty (np. Asia Express) i produkuje in house.

W tym kontekście za przełomową innowację w zakresie dystrybucji kontentu TVN należy uznać utworzenie wspólnej platformy SVOD i VOD z Polsatem. Połączony serwis Playera i Ipla będzie konkurował z Netflixem, HBO GO i Amazonem Prime.

Wierzymy, że właśnie teraz jest najlepszy moment, aby nadawcy telewizyjni tworzyli wspólnie produkty odpowiadające na potrzeby konsumentów. Polscy widzowie mają dostęp do wielu serwisów z produkcjami międzynarodowymi, a nasza inicjatywa będzie dla nich naturalną platformą oferującą polskie treści ${ }^{4}$

- informowała Katarzyna Kieli, prezes i dyrektor zarządzająca Discovery w regionie EMEA i jednocześnie szefowa Rady Nadzorczej TVN. Nowa platforma będzie

4 Zob.https://www.wirtualnemedia.pl/artykul/tvn-i-polsat-wspolna-platforma-streamingowa-start-ceny-opinie-ostatni-moment-na-taki-projekt (dostęp: 8.02.2020). 
udostępniać kontent TVN i programy Polsatu, jednak warto zauważyć, że od samego powstania obie komercyjne stacje telewizyjne były naturalnymi konkurentami. Jak to ujął w 2017 toku Edward Miszczak, dyrektor programowy TVN:

Wszystko jest konkurencją. Między mną a panią Terentiew jest twarda, zdrowa, rywalizacja, lubimy się, jestem jej fanem i mam nadzieję, że ona trochę także moim. Pracujemy co prawda w sąsiednich okopach, ale w stacjach, które nadają ton rynkowi ${ }^{5}$.

Wynika $\mathrm{z}$ tego, że obie stacje będą nadal rywalizować na poziomie tradycyjnej telewizji, przygotowując konkurencyjne ramówki, ale będą też współpracować na platformie Player/Ipla, jednocząc siły przeciwko serwisowi Netflixa.

\section{Wzmocnienie roli marki w zarządzaniu formatami}

Praktyki odbiorcze współczesnego widza sprawiają, że programujący muszą inaczej spojrzeć na planowanie ramówek stacji telewizyjnych. Przede wszystkim nieskuteczne staje się budowanie wertykalnego flow (idea przepływu widzów pomiędzy kolejnymi dziennymi pozycjami ramówki) oraz horyzontalnego flow (idea powrotu odbiorców przed telewizor o stałej porze przez cały tydzień) [Ihlebeak 2014, s. 480]. Programujący próbują odsyłać widzów od tradycyjnej telewizji na inne platformy, odrywać ich od tradycyjnych pasywnych praktyk oglądania i zachęcać do nawigowania $\mathrm{w}$ poszukiwaniu dodatkowych treści w social mediach, na dedykowanych stronach internetowych, platformach VOD lub SVOD. Programujący posługują się określeniem „uniwersum”, które ma ograniczać aktywność widowni. To uniwersum nie stanowi jedynie sumy wymienionych technologicznych możliwości, ale raczej jest pomyślane jako wspólny profil, dający się łatwo zidentyfikować, jako marka budująca grupę lojalnych odbiorców [Ihlebeak 2014, s. 480].

Kategorię marki można zdefiniować bardzo szeroko [Siegert 2017], np. jako idee wywołujące u widzów skojarzenia na poziomach: emocjonalnym, stylistycznym, kognitywnym, świadomym i nieświadomym. Można rozróżnić zatem marki kanałów telewizyjnych i podmarki (sub-brands), formaty, a także osobiste marki, np. celebrytów. Medialne marki pomagają odbiorcom wyrazić społeczną przynależność i tożsamość albo też, parafrazując Pierre’a Bourdieu, zbudować i wyzwolić ich kulturowy kapitał.

Zgodnie z zasadami ekonomii afektywnej nadawcy sprzedają reklamodawcom nie tyle kontent, ile widownię, która ten kontent pokocha (lovemarks). Jednak kreowanie marek i podmarek stało się dzisiaj procesem szczególnie skomplikowanym ze względu na istotną zmianę łańcucha wartości przemysłu medialnego [Siegert 2015]. Tradycyjnie łańcuch wartości zakładał procesy: pozyskiwania, kreowania, wybierania, organizowania i przystosowania kontentu do marketingu, reklamy,

5 Zob.https://www.wirtualnemedia.pl/artykul/edward-miszczak-nie-jestem-fundamentalistadla-zdrad-gwiazd-jestem-wyrozumialy (dostęp: 8.02.2020). 
promocji i dystrybucji. Jednak dzisiaj platformy, które są w istocie agregatorem kontentu, utrudniają prostą identyfikację marki. Widzowie kojarzą markę Netflixa, nie przywiązują jednak wagi do brandów poszczególnych programów, które oglądają w serwisie. Zachowanie widzów jest mobilne, nielinearne, modularne, niezależne od jednej platformy. W związku z tym przedsiębiorstwa medialne muszą budować lojalność wobec marki, relację z marką wszędzie, gdziekolwiek odbiorca się z nią zetknie.

Przykładem udanych strategii brandingu są często formaty należące do obszaru talent show, które tworzą trwałe relacje $\mathrm{z}$ widzami/konsumentami, budują lojalność i zaufanie także do „nowo powstałych marek”, które pojawiają się w trakcie programu. W tym wypadku liczy się wiarygodność pierwotnego brandu formatu, który gwarantuje autentyczność rodzących się talentów - nowych marek: gwiazd muzyki, tancerzy, szefów kuchni. Widzowie wierzą, że środowisko programu stwarza kontekst, w którym mogą się pojawić wartościowe brandy, warte zapamiętania i śledzenia. Te formaty stanową zatem rozległy marketingowy projekt.

W dobie konwergencji widz staje się często współtwórcą, a nie tylko odbiorcą programu telewizyjnego. Format musi być tak skonstruowany, żeby pozwolić widzom na tę aktywność [Coletta 2016]. Licencje nie tylko zakładają różnorodny udział odbiorców w tworzeniu formatu, lecz także dają przyzwolenie na projektowanie opowieści transmedialnych, które czasem wymykają się spod kontroli nadawców i producentów.

Trudno pominąć też wpływ formatów telewizyjnych na kulturę organizacyjną korporacji medialnych, które eksplorują narrację show na potrzeby nie tylko marketingu, ale też komunikacji wewnętrznej. Sukces największych globalnych spółek, takich jak Apple, Netflix, IKEA, był wspierany przez zaangażowanie samych pracowników, którzy utożsamiali się z marką tych organizacji [Coletta 2016].

\section{Zakończenie}

Celem tego artykułu było opisanie, w jaki sposób strategiczne lub operacyjne działania podejmowane przez organizacje medialne w odpowiedzi na zmieniający się rynek telewizyjny wpływają na funkcjonujący dotychczas model handlu formatami. $\mathrm{Ze}$ względu na obszerność tego zagadnienia zostały wzięte pod uwagę praktyki głównych podmiotów zarządzania formatami globalnymi: twórców formatów, nadawców, dystrybutorów i producentów. Ten wybór został podyktowany ekonomicznym, społecznym i kulturowym wymiarem handlu formatami. Trzeba zauważyć, że przez dwie dekady wypracowano model funkcjonowania w tym obszarze, pozwalający na odnalezienie równowagi w konceptualnej ramie wyznaczonej przez opozycje:

1. adaptacji versus kreacji;

2. nadawców versus spółek zależnych od globalnych graczy;

3. uwarunkowań globalnych versus lokalnych;

4. wartości biznesowych i kulturowych [Nyland 2016]. 
Ta równowaga może zostać zakłócona w wyniku opisanych powyżej działań strategicznych i operacyjnych podejmowanych przez globalne podmioty.

Przejmowanie kontroli nad produkcją przez spółki zależne, ekspansja zagranicznego kapitału oraz nowe kanały dystrybucji mogą skutkować mniejszym udziałem nadawców w kreacji, uniwersalizacją formatów pozbawionych lokalnych akcentów, a także osłabianiem marki podmiotów identyfikowanych na lokalnych rynkach.

W efekcie wydaje się, że opisane zmiany, podyktowane przede wszystkim ekonomicznym interesem korporacji medialnych, mogą wpłynąć na stabilny i utrwalony przez dwie dekady model zarządzania formatami, który zdefiniował równowagę między biznesowym a kulturowym wymiarem.

\section{Bibliografia}

Anderson Ch., The Long Tail: Why the Future of Business Is Selling Less of More, Hyperion, 2006. Biltereyst D., Soberon L., Formatting Reality: On Reality Television as a Format, a Genre and a Meta-Genre, [w:] K. Aveyard, P. Majbritt, A. Moran, P.M. Jensen (red.), New Patterns in Global Television Formats, Intellect, Bristol 2016, s. 49-62.

Bodycombe D., What Is a Format? FAQ, http://www.tvformats.com/formatsexplained.htm. (dostęp: 15.10.2019).

Bourdon J., From Discrete Adaptations to Hard Copies: The Rise of Formats in European Television, [w:] T. Oren, F. Shahaf (red.), Global Television Formats, Routledge, London 2012, s. $111-127$.

Chalaby J.K., The Format Age: Television's Entertainment Revolution, Polity Press, Cambridge 2016.

Coletta C., The Hybrid Status of Global Television Formats, [w:] K. Aveyard, P. Majbritt, A. Moran, P.M. Jensen (red.), New Patterns in Global Television Formats, Intellect, Bristol 2016.

Crew E., How Real Is Survivor for Its Viewers?, [w:] D.S. Escoffery (red.), How Real Is Reality TV? Essays on Representation and Truth, McFarland, Jefferson, NC 2006, s. 61-78.

Cury I., Directing and Producing for Television: A Format Approach, Focal Press, Amsterdam 2007.

De Bruin J., Zwaan K. (red.), Global Television Format, Routledge, London-New York 2012.

Fairchild Ch., Building the Authentic Celebrity: The "Idol" Phenomenon in the Attention Econo$m y$, „Popular Music and Society” 2007, vol. 30, nr 3, s. 355-375.

Franck E., Nuesch S., Avoiding “Star Wars” - Celebrity Creation as Media Strategy, „KYKLOS” 2007, nr 2, s. 211-230.

Fursich E., Between Credibility and Commodification: Non-Fiction Entertainment as a Global Media Genre, „International Journal of Cultural Studies” 2003, nr 2, s. 131-153.

Ihlebeak K.A., Syvertsen T., Ytreberg E., Keeping Them and Moving Them: TV Sheduling in the Phase of Channel and Platform Proliferation, „Television \& New Media” 2014, vol. 15, s. $470-486$.

Kraidy M.M., Rethinking the Local-Global Nexus Through Mulitiple Modernities: The Case of Arab Reality Television, [w:] A. Moran (red.), TV Formats Worldwide: Localizing Global Programs, Intellect, Bristol-Chicago 2009.

Moran A. (red.), TV Formats Worldwide: Localizing Global Programs, Intellect, Bristol-Chicago 2009. 
Moran A., Copycat Television. Globalisation: Program Formats and Cultural Identity, Luton University Press, Luton 1998.

Nylund M., Television Format as a Transnational Production Model, [w:] K. Aveyard, P. Majbritt, A. Moran, P.M. Jensen (red.), New Patterns in Global Television Formats, Intellect, Bristol 2016, s. 19-34.

Oren T., Shahaf S. (red.), Global Television Formats: Understanding Television across Borders, Routledge, London-New York 2012.

Schmitt D., Bisson G., Fey Ch. (red.), The Global Trade in Television Formats: Market Research Report, Screen Digest, London 2005.

Siegert G., Förster K., Chan-Olmsted S.M., Ots M. (red.), Handbook of Media Branding, Springer, Zurich 2015.

Torre P., Television Formats and the United States: New Developments in Production and Distribution, „International Journal of Digital Television” 2017, vol. 8, nr 1.

Van den Bulck H., Enli G.S., Flow under Pressure: Television Scheduling and Continuity Techniques as Victims of Media Convergence?, „Television \& New Media” 2014, nr 5, s. 449-452.

Waisbord S., McTV: Understanding the Global Popularity of Television Formats, „Television \& New Media” 2004, nr 5, s. 359-383.

Waisbord S., Jalfin S., Imagining the National: Television Gatekeepers and the Adaptation of Global Franchises in Argentina, [w:] K. Aveyard, P. Majbritt, A. Moran, P.M. Jensen (red.), New Patterns in Global Television Formats, Intellect, Bristol 2016.

\section{Strony internetowe}

https://www.nordicom.gu.se/en/latest/news/tv-viewing-nordic-countries-2016 (dostęp: 8.02.2020). https://www.wirtualnemedia.pl/artykul/discovery-z-tvn-i-cyfrowy-polsat-uruchomia-wspolny-serwis-vod-player-i-ipla-maja-dzialac-nadal (dostęp: 8.02.2020).

https://www.wirtualnemedia.pl/artykul/edward-miszczak-nie-jestem-fundamentalista-dla-zdrad-gwiazd-jestem-wyrozumialy (dostęp: 8.02.2020). 